\title{
Education and Socio-Economic Development of Kaivartta Community
}

\author{
Dilip Das, Nobin Chandra Das
}

\begin{abstract}
Education brings rapid changes into socio-economic and cultural aspect of a society. So, education is the most important parameter of upward social mobility. This paper is an attempt to analyse the impact of education among Kaivartta of Majuli Island, Assam. The data have been collected from primary and secondary sources from six Kaivartta inhabited villages. The study demonstrates that educational attainment tends determined occupational choice, income level, social status and life style of an individual.
\end{abstract}

Key words: Education, Occupation, Income, Social Mobility, Kaivartta, Majuli.

\section{INTRODUCTION}

Education in ancient India was confined to a small section of society. Access of common people to education was excluded due to religious, caste and gender discrimination. The Hindu caste based social system separated human being into a hierarchy of ascent and descent. Caste hierarchy brings stay alive the thoughts of superiority and inferiority in ancient India social system. Therefore lower castes also known as: Sudra, Avarna, Chandala, Dharmahina, untouchable, outcaste, exterior caste, depressed caste, had been socially, economically and culturally exploited for centuries which are listed later on as Scheduled Caste.

After independence, constitution of India has made provision of protective discrimination policy, especially reservation policy. Thus, the constitution of India made provision of reservation of seat for Scheduled Caste in the sphere of education, public employment, and central and state legislatures. Implementation of reservation policy played a catalyst role in securing overall development of Scheduled Caste. Education for scheduled caste has become a part of national educational system. Government had formulated various schemes and policies for educational development of scheduled caste people in entire country. So, education plays crucial role in enabling Scheduled Caste to access socio-political, cultural and economic development.

The Kaivarttas are one of the sixteen scheduled castes communities of Assam. They are economically back ward and social deprived. They are fishermen by profession. In socially and geographically diversified Indian society, the fishermen could not achieve socially sanctioned position in broad spectrum of society.

Revised Manuscript Received on January 29, 2020.

* Correspondence Author

Nobin Chandra Das*, Assistant Teacher, Government School Under Assam Government, Assam, India.

Dilip Das, Assistant Teacher, Government School Under Assam Governmennt, Assam, India.

(c) The Authors. Published by Blue Eyes Intelligence Engineering and Sciences Publication (BEIESP). This is an open access article under the CC BY-NC-ND license (http://creativecommons.org/licenses/by-nc-nd/4.0/)
Moreover, this community could not come in public interest for a long time due to some unavoidable circumstances such as physical and geographical obstruction, socio-cultural isolation, lack of communicative representation and leadership. Scholars opine that caste discrimination, atrocity and exploitation are relatively less in Assam in comparison to other states in India and they are in better position. Besides, numerous studies have shown that participate in education among scheduled castes are significantly increasing after post-independent era. Now, question arises whether education contributed to socioeconomic development of the Kaivarttas of Majuli to attain a greater social mobility. Keeping view on it present study is undertaken.

\section{OBJECTIVES}

The objectives of the study includes-

1. To study the educational attainment level among Kaivarttas.

2. To analyse the interrelationship of education and socioeconomic development among Kaivarttas.

\section{METHODOLOGY}

Present study is under taken among the Kaivarttas of Majuli district, Assam. There are two development blocks in Majuli viz. Majuli Development Block and Ujani Majuli Development Block consist 42 Kaivartta inhabited village. From each development block four Kaivartta inhabited villages are purposively selected. The selected villages are Rangali Bahar, Bhuramara No. 2, Senchowa Alengiati and Barmukali Kaivartta. In sample selection each family has been given equal opportunity of selection. Out of total 288 families of the selected villages, 106 families (approximately 37\%) have been selected as unit of sample through simple random sampling method (lottery method) for well representation of the study and earner of the family regarded as respondent. Primary data are collected through structured interview scheduled. Books, Journals, Government records are use as a secondary data. The study has analysis empirical data in comparative perspective of education and socio-economic development of the Kaivartta of Majuli district and findings are drowning mainly by descriptive and analytical method. Quantitative methods like tabulation, frequency distribution, percentage are also used for data analysis.

\section{EDUCATION AND KAIVARTTA}

Education is the key factor of overall development of a society. In middle age, Satras are playing vital role for spread of Sanskit education in Assam.

\section{Published By:}

Blue Eyes Intelligence Engineering

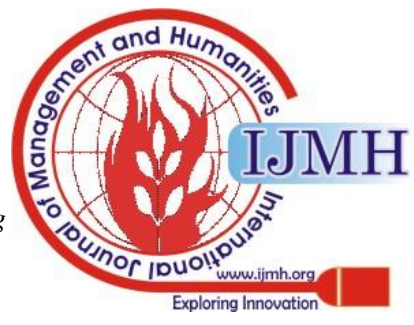




\section{Education and Socio-Economic Development of Kaivartta Community}

In Majuli priest and Vaishnavas helped to expand Sanskrit education among Satradhikar. Modern education in Majuli Island was introduced during colonial period. Kaivartta inhabited area of the island received little attention of social workers and policy maker during British period.

During field study it is observed that not a single primary school was established during that period in Kaivartta inhabited area. Though impact of modern education is late, literacy rate of the study village is satisfactory. Among them 85\% percent is literate whereas 14.15 are found illiterate (Table 1).

Table 1: Literacy Rate of Respondent

\begin{tabular}{|c|c|c|}
\hline Literacy & Respondent & Percentage \\
\hline Literate & 91 & 85.84 \\
\hline Illiterate & 15 & 14.15 \\
\hline Total & 106 & $100 \%$ \\
\hline
\end{tabular}

Source: Field Study during 5th Oct-28 Dec, 2017

\section{EDUCATIONAL ACHIEVMENT AND OCCUPATION}

There is a close relationship between educational achievement and occupation, since level of educational attianment determines a person occupation. In present society education is the most important factor which determine occupation and income of a person one can aspire. To examine the educational achievement of the Kaivarttas under study is divided into five categories viz. upper primary, under matriculation, HSSLC, graduate, postgraduate and techinal and professional. Table 2 clearly depicts the educational achievement and occupation.

Table 2: Educational Achivement and Occupation

\begin{tabular}{|c|c|c|c|c|c|c|}
\hline \multirow[b]{2}{*}{$\begin{array}{c}\text { Educationa } \\
\text { l Level }\end{array}$} & \multicolumn{5}{|c|}{ Occupation } & \multirow[b]{2}{*}{ 퓸 } \\
\hline & 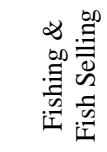 & 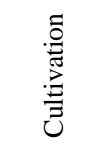 & 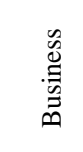 & $\sum_{\mathscr{n}}^{\mathscr{n}}$ & 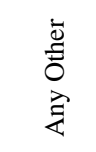 & \\
\hline Illiterate & 320.0 & 960.0 & - & - & 320.0 & $\begin{array}{l}1514.1 \\
5\end{array}$ \\
\hline $\begin{array}{l}\text { Upper } \\
\text { Primary }\end{array}$ & 12.56 & $\begin{array}{c}2974.3 \\
5\end{array}$ & 12.56 & - & 820.51 & $\begin{array}{c}3936.7 \\
9\end{array}$ \\
\hline $\begin{array}{c}\text { Under } \\
\text { Matriculati } \\
\text { on } \\
\end{array}$ & 27.14 & $\begin{array}{c}1760.7 \\
1\end{array}$ & 310.71 & - & 621.42 & $\begin{array}{c}2826.4 \\
1\end{array}$ \\
\hline H.S.S.L.C & - & 535.71 & 535.71 & $\begin{array}{c}17.1 \\
4\end{array}$ & 321.43 & $\begin{array}{c}1413.2 \\
1\end{array}$ \\
\hline Graduate & - & 112.5 & 450.0 & $\begin{array}{c}337 . \\
5\end{array}$ & - & 87.54 \\
\hline
\end{tabular}

\begin{tabular}{|c|c|c|c|c|c|c|}
\hline $\begin{array}{c}\text { Post } \\
\text { Graduate }\end{array}$ & - & - & - & $\begin{array}{c}2 \\
33.3\end{array}$ & - & 2 \\
\hline $\begin{array}{c}\text { Technical/ } \\
\text { professiona } \\
\text { l }\end{array}$ & - & - & - & - & - & - \\
\hline Total & 6.66 & 61.55 & 13.26 & 5.66 & $\begin{array}{c}20 \\
18.86\end{array}$ & 106 \\
\hline
\end{tabular}

Source: Field Study during $5^{\text {th }}$ Oct-28 Dec, 2017

*Any Other: Wage earner, Carpenter, Driver

It is clear from above analysis that majority of respondent are educated up to upper primary (36.79\%) level most of them are engaged in cultivation (74.35\%). Among the respondent $7.53 \%$ completed graduation and $50 \%$ of them engage in business whereas $37.5 \%$ doing government service. The study found that only 2 i.e. $1.88 \%$ respondent achieved highest education.

\section{EDUCATION AND ECONOMIC DEVELOPMENT}

There is a close relationship between education, occupational achievement and income. Individual with low level of education have lower income than those with higher level of education (Sewell and Hauser, 1975). Because a low educated person is less likely to be employed, and if employed, he is more likely to hold low level job. To understand about annual income level of the respondent, the level of the income is divided into eight categories; viz. less than $10,000,10,500-15,000,15,500-20,000,20,500-25,000$, $25,500-30,000, \quad 30,500-35,000, \quad 35,500-40,000, \quad 45,500-$ 50,000 .

Table 3 reveals that out of 106 sample respondent of the study area 43 i.e. $40.56 \%$ annual income is less than 10,000 of which $17.03 \%$ earner is under matriculation, $12.26 \%$ is upper primary and illiterate as well. Within the income category $15,500-25,0009.43 \%$ earner is upper primary, $4.71 \%$ is under marticulation $7.54 \%$ having HSSLC and $1.88 \%$ is graduate. There is $2.83 \%$ respondent having annual income is Rs. $25,500-30,000$ and $0.94 \%$ of them achieved education up to matriculation and $1.88 \%$ is graduate. In the field situation there is no respondent found in the income category of Rs 30,500-40,000. Out of total respondent only $1.88 \%$ is achieved highest educational level i.e. post graduation depends on government service and their monthly income level is more than 40,500-50,000 and more than 50,000 per month. There is no respondent found engaged in technical area in the study villages.

Table 3: Educational Achievement and Income of Respondent

\begin{tabular}{|l|c|c|c|c|c|c|c|c|}
\hline \multirow{2}{*}{ Annual Income } & \multicolumn{9}{|c|}{ Education of Respondents } & \multirow{2}{*}{ Total } \\
\cline { 2 - 8 } & Illiterate & $\begin{array}{c}\text { Upper } \\
\text { Primary }\end{array}$ & $\begin{array}{c}\text { Under } \\
\text { Matriculation }\end{array}$ & HSSLC & Graduate & $\begin{array}{c}\text { Post } \\
\text { Graduate }\end{array}$ & $\begin{array}{c}\text { Technical// } \\
\text { Professional }\end{array}$ & \\
\hline Less 10,000 & $13(12.26)$ & $13(12.26)$ & $17(16.03)$ & - & - & - & - & $43(40.56)$ \\
\hline $10,500-15,000$ & $2(1.88)$ & $10(9.43)$ & $4(3.77)$ & - & - & - & - & $16(15.09)$ \\
\hline $15,500-20,000$ & - & $10(9.43)$ & $5(4.71)$ & $8(7.54)$ & $2(1.88)$ & - & - & $25(23.58)$ \\
\hline $20,500-25,000$ & - & $6(5.66)$ & $2(1.88)$ & $6(5.66)$ & $4(3.77)$ & - & - & $18(16.98)$ \\
\hline $25,500-30,000$ & - & - & $1(0.94)$ & - & $2(1.88)$ & - & - & $3(2.83)$ \\
\hline $30,500-40,000$ & - & - & - & - & - & - & - & - \\
\hline $40,500-50,000$ & - & - & - & - & - & $1(0.94)$ & - & $1(0.94)$ \\
\hline Above 50,000 & - & - & - & - & - & $1(0.94)$ & - & $1(0.94)$ \\
\hline Total & $12(11.32)$ & $39(36.79)$ & $28(26.41)$ & $14(13.20)$ & $8(7.54)$ & $2(1.88)$ & - & $106(100)$ \\
\hline
\end{tabular}

Source: Field Study during $5^{\text {th }}$ Oct-28 Dec, 2017 


\section{RESULT AND DISCUSSION}

i. Though, overall literacy rate of the Kaivartta is $85.84 \%$, they are not well educated. Out of 106 respondents 39 i.e. $36.79 \%$ is achieved education up to upper primary, 28 i.e. $26.41 \%$ is under matriculation, 14 i.e. 13.20 is HSSLC passed whereas only $7.54 \%$ is found graduation. Only a negligible portion of Kaivartta that is $1.88 \%$ able to achieved highest educational level. In the field situation it is observed that there are not a single person achieved technical education.

ii. As it is mentioned earlier that education determines occupation of a person. It is clear from the study that out of 15 i.e. $15.14 \%$ illiterates, $60 \%$ is engaged in cultivation and $20 \%$ of each engaged in their traditional occupation as well as any other occupation. Majority of the Kaivartta those who educated up to upper primary, $74.35 \%$ is engaged in agriculture. Similarly, $60.71 \%$ of under matric Kaivarttas also engaged in the same occupation. Out of total 14 HSSLC passed only 1 i.e. $7.14 \%$ is engaged in service whereas out of 8 graduate only 4 i.e. $50 \%$ is engaged in service. Though younger generation of the community able to achieved higher education, they are suffering in unemployment. They are even self employed themselves since there is no industry, lack of transport and communication for business since Majuli island is isolated place where backwardness is observed in every aspect. Young educated generation migrate to Kerela, Hyderabad and neighbouring states and engaged themselves as security guard, various factories, telecommunication centre to earn their daily bread-and-butter.

iii. As we know occupation determines the income level of a person. In the study, it is found that majority i.e. $40.56 \%$ respondent annual income is less than 10,000 of which $12.26 \%$ earner is illiterate, $12.26 \%$ have primary education and $16.03 \%$ is under matriculation whereas it is found that only $0.94 \%$ of Kaivartta belongs to income level of 40,000-50,000 or more than 50,000 among them who achieved the highest level of education.

iv. Educated younger generation feel inferior to practice fishing and fish selling since the profession considered as derogatory. They desire to enhance their social recognition in entire society. But mention may be made, the illiterate, who utilized labour in fishing and fish selling, agriculture and other economic activities cannot meet up their day to day problems due to some unavoidable circumstance such as unavailability of fishes, scared agricultural land, and lack of modern fishing methods. There income is irregular and insufficient.

\section{CONCLUSION}

From above discussion we may conclude that geographically isolated Majuli Island has miscellaneous problems such as flood and bank erosion. So, life of the isolated Kaivartta of the island is full of uncertainty and danger. Overall condition of the Kaivartta of Majuli Island is poor, backward and below average in all aspects of life. But still there is a ray of hope that one day Kaivartta of the remote island will overcome from all sorts of backwardness. It is distinguished the study may not be represent a comprehensible picture of Kaivartta as a whole since this study is micro level observation based on only four Kaivartta inhabited village of Majuli.

\section{REFERENCES}

1. Barpujari, H.K. 1992. Christian missionaries in North-east India. Pp. 176.

2. Goswami, Atul C. 2001. Majuli adhunik siksha sampacharn (an Assamese article). In P. Mahanta (ed.) Majuli (pp. 187-188), Jorhat: New Area Media Service.

3. Nath, D. (2009). The Majuli island: Society, economy and culture. Delhi: Anshah Publishing House. Pp. 99.

4. Neog, M. (1965). Sankaradeva and his times: Early history of the Vaishnava faith and movement in Assam, $1^{\text {st }}$ edition, Gauhat University. Pp. 110.

5. Thakur, Bhuban C. 2001. Siksha bivinna disat alokpat (an Assamese article). In P. Mahanta (ed.) Majuli (pp. 188-203), Jorhat: New Area Media Service.

6. Mahanta, P.K. (ed.) 2001. Majuli. Jorhat: New Area Media Service Pp.23.

7. Sarma, Chandana 2010. The Kaivarttas: A study of socio-economic life in three villages in Assam. Guwahati: Bhoniman Printer. Pp. 132.

8. Sarma, Tirthanath 1975. Auniati satra buranji. Auniti, Pp. 280, 311.

9. Sewell, William H. and Hauser, Robert M. 1975. Education, occupation and earning. New York: Academic Press. Pp. 12.

10. Sharma Ram Nath and Sharma Rajendra Kumar 1996 History of Education in India, Delhi, Atlantic Publishers, Pp. 1-20.

11. Yusuf, Noah. 2009. Impact of education on social mobility among residents on Ilorin Metropolis. International Multi-Disciplinary Journal, 3(1), 373-387.

\section{AUTHORS PROFILE}

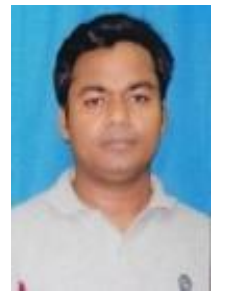

Nobin Chandra Das, he was born in Majuli on 28 February, 1983. He pursued graduation in department of Sociology, Pub Majulli College, Majuli and then obtains M.A. in Sociology from Dibrugarh Univarsity, Dibrugarh. He has completed

Doctor of Philosophy from Assam University, Silchar (A Central University, Act 1989) under supervisor of Dr. Nirakar Mallick on the topic "The Kaivarttas in Majuli: An Ethnographic Study". He has around four years teaching experiences as assistant professor in the department of Sociology of Mahatma Gandhi University (private), Meghalaya. He has 7 publications having ISSN \&ISBN in international journal and edited book. He has permanent membership in Indian Sociological Society, India Now; he is working as assistant teacher in a government school under Assam Government. He has also pursued D.El.Ed (NIOS).

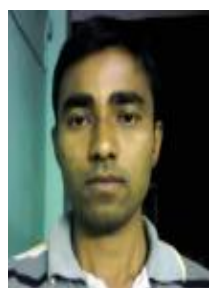

Dilip Das, He was born in Majuli on 1 Feb, 1983. He pursued graduation in department of Assamese from Majuli College, Majuli and then obtains M.A. in Assamese from Dibrugarh University, Dibugarh.

He has completed Master of Philosophy from Assam University, Silchar (A Central University, Act 1989) under the supervisor of Dr. Kusumbar Barouah. He has around two Years teaching experiences as assistant professor in the department of Assamese of Tingkhong and Rangachahi college, Dibrugarh. He has 5 Publications having ISSN\&ISBN in international journal and edited book. Now, he is working as assistant teacher in a government school under Assam Governmennt. He has also pursued D.El.Ed (NIOS). 